\title{
Fertility of degraded chernozem in short grain-beet crop rotations
}

\author{
Tsvei Ya. \\ doctor of agricultural science, professor, head of agroecomonitoring and husbandry problems \\ department \\ Ivanina V. \\ doctor of agricultural science, head of agrochemistry department \\ Institute of Bioenergy Crops and Sugar Beet NAAS \\ Lenshyn 0. \\ candidate of agricultural science \\ Khmelnitska State Agricultural Research Station of Institute for Feed of Podillia Agriculture NAAS
}

The purpose. To study influence of structure of crop rotation upon agrochemical and physicochemical parameters of fertility of degraded chernozem at application of organic-and-mineral fertilizer system and long-term growing of crops. Methods. Long-term field and analytical. Results. Changes of nutritive regime and physical and chemical properties of degraded chernozem are shown at different saturation of crop rotation by perennial grasses, row crops, grain and leguminous crops. Conclusions. On completion of two rotations the highest content of humus in degraded chernozem on the background of dung in dose of 7,5 t/hectare $+\mathrm{N}_{45} \mathrm{P}_{45} \mathrm{~K}_{35}$ for 1 hectare of crop rotation area is determined in crop rotations of the following structures: 1) a share of cultivated crops in crop rotation - up to $25 \%$, perennial grasses - up to 25 , grain - more than $50 \%$; 2) a share of leguminous cultures $-25 \%$, grain -50 , row crops $-25 \%$. Increase of a share of cultivated crops in crop rotation up to $50 \%$ aggravated physical and chemical soil characteristics: $\mathrm{pH}$ salt dropped to $5,6-5,7, \mathrm{Ng}$ - increased up to $2,2-2,5 \mathrm{mg}$-eq./100 g, $\mathrm{S}-$ dropped to $22,0-23,6 \mathrm{mg}$-eq./100 $\mathrm{g}$ of soil. Saturation of crop rotation by row and cereal crops had no essential influence on phosphatic and potash regimes of soil. The optimum content of mobile phosphorus and potassium in degraded chernozem was observed at use in crop rotation of buckwheat and pease.

Key words: humus, degraded chernozem, links of crop rotation, fertilizer system.

Introduction. The formation of sustainable agro-ecosystems in agriculture is closely linked to the optimization of crop rotation and fertilizer system. In recent years, the specialization of farms has become substantially narrower, agrarian production has concentrated on the cultivation of selected economically attractive crops. The consequence of such a transformation was the systematic changes in the structure of crop rotation, the abandonment of perennial grasses, the violation of small biological circulations of substances, which caused a critically negative balance of carbon and nutrients in agro-ecosystems [1,2].

Reducing the share of wide raw crops in crop rotation, optimizing the fertilizer system can significantly reduce the technogenic load and loss of humus in agro-ecosystems, create the prerequisites for the restoration of natural fertility of soils [3, 4].

Formation of crop rotations and application of fertilizers should be aimed at optimization of physical and chemical parameters, ensuring a positive balance of organic matter and nutrients in the soil $[5,6,7,8,9,10]$.

Investigation purpose was to study an influence of crop rotation structure on the change of natural soil fertility in podsolic black soil for long term crops growing.

Materials and investigation methods. Investigations were carried out in short term crop rotations of Khmelnitska State Agricultural Research Station NAAS on expiration of second crop rotation.

Soil of research plot of land is podsolic black soil with the following agrochemical characteristic of topsoil (0-30 cm): pH salt solution - 5,6-6,2; hydrolytic acid (by Kappen) - 1,7-2,1 mg-eq./100 g of soil; soil base saturation (by Kappen-Gilkovits) - 37,9-42,2 mg-eq./100 g of soil; organic matter content (by Thurin) - 3,5\%; 
mineral nitrogen (nitrate and ammonium) by TsINAO methodic $-65-83 \mathrm{mg} / \mathrm{kg}$ of soil; mobile phosphoric and potassium (by Chirikov) reciprocally $-163-178$ and $55-73 \mathrm{mg} / \mathrm{kg}$ of soil.

Site drilling area $-175 \mathrm{~m}^{2}$, site accounting area $-100 \mathrm{~m}^{2}$, repetition - four-time. Investigation was carried out on the background of the organo-mineral system of fertilizers with application of 7.5 tons of manure + N45P30K35 per 1 hectare of crop rotation area, including for sugar beet -30 tons of manure + N90P80K90, winter wheat, barley and buckwheat - N45P20K30 each (for the preliminary crop of winter wheat fertilizers were not applied).

Alternation of crops in rotations: 1 . Clover - winter wheat - sugar beet - barley + clover; 2. Pea for grain winter wheat - sugar beet - spring wheat; 3 . Corn sown with soybean for silage - winter wheat - sugar beet spring wheat; 4. Buckwheat - winter wheat - sugar beet - spring wheat; 5 . Corn sown with soybean for silage - winter wheat - sugar beet - buckwheat; 6 . Spring barley - winter wheat - sugar beet - buckwheat; 7. Pea for grain - winter wheat - sugar beet - buckwheat; 8 . Pea for grain - winter wheat - sugar beet - spring barley.

Soil samplers were taken out on the expiration of second crop rotation. The content of organic matter was determined by Thurin, $\mathrm{pH}$ of salt solution - by $\mathrm{pH}$-meter, hydrolytic acid - by Kappen, soil base saturation by Kappen-Gilkovits, nitrate and ammonium nitrogen - by TsINAO methodic, mobile phosphoric and potassium - by Chirikov.

Investigation results ant their discussion. Studies have shown that for prolonged use of the organicmineral system of fertilizers $\left(7.5 \mathrm{t} /\right.$ ha manure $+\mathrm{N}_{45} \mathrm{P}_{30} \mathrm{~K}_{35}$ per 1 hectare of crop rotation area) in crop rotation with the share of perennial grasses $-25 \%$, cereals $-50 \%$, fertilizers $-25 \%$, content of humus in the soil at the end of the second rotation was $3,64 \%$ in the topsoil $(0-30 \mathrm{~cm}), 2,82 \%$ in down $(30-50 \mathrm{~cm})$ layer. The increase of wide raw crops in crop rotation up to $50 \%$ (corn sown with soybean for silage - $25 \%$, sugar beet $25 \%$ ) with share of cereal $-50 \%$ (winter wheat - $25 \%$, spring wheat - $25 \%$ ) caused a decrease of organic matter content in the soil in comparison with cereal-grass-wide raw crop rotation in the topsoil - per $0.11 \%$, sub-soil - per $0.12 \%$, when absolute values of indexes were respectively $3.53 \%$ and $2.70 \%$. This decrease is caused by the intensive mineralization of soil organic matter, which is one of the main causes of humus losses in modern, oriented to cultivating wide raw crops, systems of husbandry. A similar pattern was observed in cereal-wide raw crop rotation for saturation with buckwheat $-25 \%$, winter wheat $-25 \%$, wide raw crops - $50 \%$ (corn sown with soy bean - $25 \%$, sugar beet - $25 \%$ ) (table 1 ).

In short-term crop rotations when share of wide raw crops does not exceed $25 \%$, with saturation by cereals - $75 \%$, the organic matter content in the soils was the close to the level of cereal-grass-wide raw crop rotation. Thus, in cereal-wide raw crop rotation, where, after spring cereal, peas were sown for grain (peas for grain - winter wheat - sugar beet - spring wheat), the content of organic matter in topsoil $(0-30 \mathrm{~cm})$ was $3.62 \%$, subsoil $(30-50 \mathrm{~cm})-2.70 \%$, which was only slightly lower than in cereal-grass-wide raw crop rotation - per $0.02 \%$ and $0.04 \%$ respectively. Such a slight decrease in the organic matter content may be due to lower amounts of accumulation of biological nitrogen in the soil after peas in comparison with the clover, which, according to studies by a number of scientists $[1,2,3,4]$, affects the intensity of humus formation. 


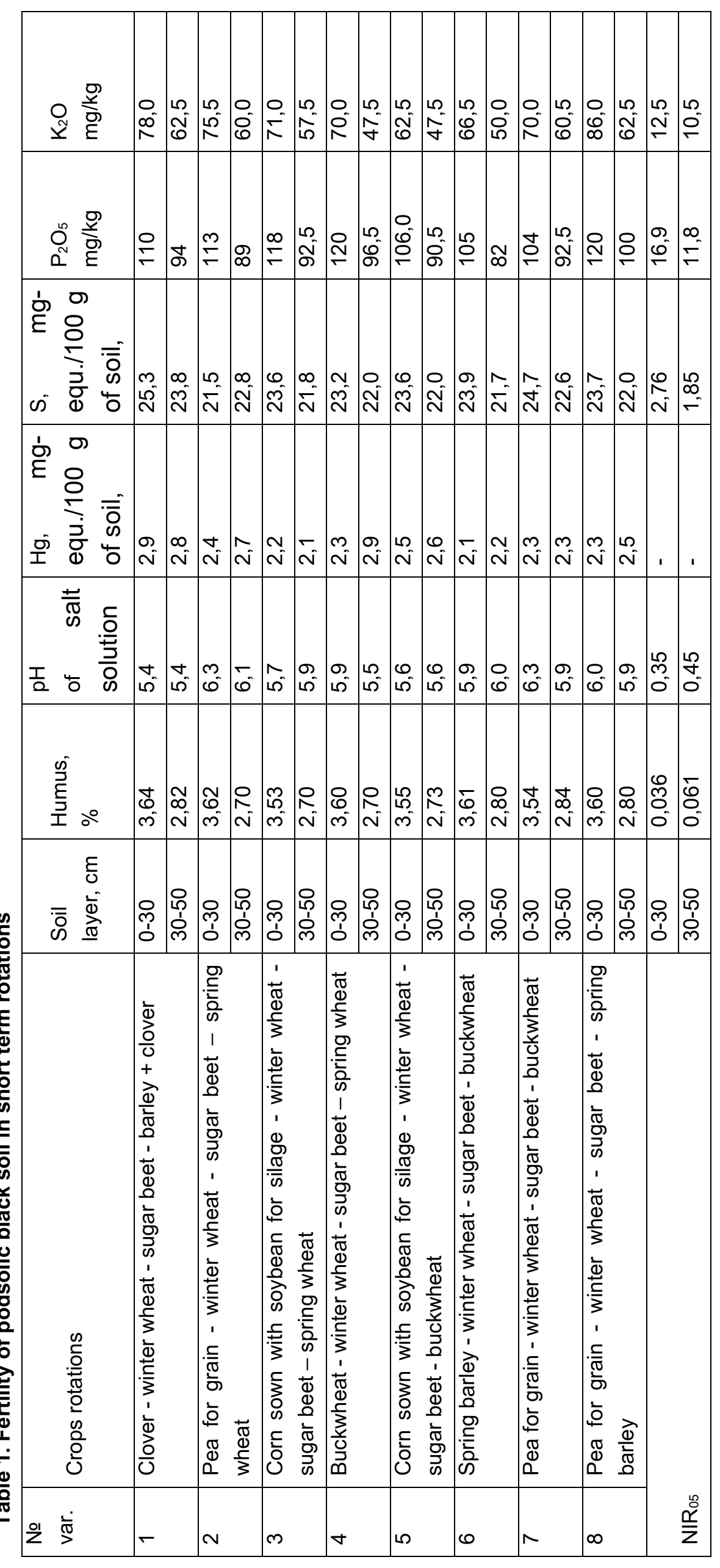


In cereal-wide raw crop rotation with alternating crops: spring barley, winter wheat, sugar beets, buckwheat, the content of organic matter in the topsoil was $3.61 \%$, for placement of buckwheat-peas as predecessors of winter wheat in the same crop rotation - $3.54 \%$, which in comparison with cereal-grasswide raw crop rotation was less per $0.03 \%$ and $0.10 \%$ respectively.

Important indicators of soil fertility are physical and chemical properties. Saturation of crop rotation with cereals, wide raw crops and leguminous crops for prolonged their cultivation can significantly affect the physical and chemical parameters of the soil [5].

Studies have shown that in cereal-sugar beet rotations with a share of peas on grain $25 \%$, the acidity of podsolic black soil was slightly lower compared to crop rotations where the maize for silage, buckwheat and clover were grown as a predecessor of winter wheat. In crop rotations with peas, the level of acidity at the end of two rotations varied in topsoil $(0-30 \mathrm{~cm})$ within 6.0-6.3. Significant increase of acidity in the topsoil and subsoil layer - up to 5.4 was observed in cereal-grass-wide raw crop rotation with the clover, as well as in crop rotations saturated with wide raw crops up to $50 \%-5.6-5.7$. Acidity of the soil was slightly lower in crop rotations with a share of cereals up to $75 \%$, including crop rotation with growing buckwheat - 5.9 .

Soil base saturation was less dependent on the structure of crop rotation, and for the long-term cultivation of crops only tended to decrease, most often it was observed in crop rotations with high up to $75 \%$ saturation with cereals - 20,0-21,2 mg ekv./100 g of soil. Probably the loss of calcium and magnesium from the soil-absorption complex has become the reason for this.

The highest value of soil base saturation was determined in cereal-grass-wide raw crop rotation - 25.3 $\mathrm{mg}$ ekv./100 g soil. At the same time, in crop rotations with a share of peas for grain up to $25 \%$, this indicator value varied within $21,5-24,7 \mathrm{mg}$ ekv./100 $\mathrm{g}$ of soil.

The best conditions for the phosphate regime in black soils are formed by the organic-mineral system of fertilizers [1, 6]. For the cereal-sugar beet rotations, phosphorous nutrition is a significant factor, since phosphorus plays an important role in increasing sugar beet productivity [8].

The results of researches showed that in crop rotation: peas for grain - winter wheat - sugar beet spring barley, the content of mobile phosphorus in topsoil and subsoil was 120 and $100 \mathrm{mg} / \mathrm{kg}$ of soil respectively. For alternation of crops in the crop rotation: buckwheat - winter wheat - sugar beet - spring wheat, the content of mobile phosphorus in the topsoil decreased to $96.5 \mathrm{mg} / \mathrm{kg}$ of soil that was due to an increase in the removal of phosphorus by cultivated crops.

In crop rotations, where corn sown with soybean for silage, spring barley and peas for grain was grown in the first field, the content of phosphorus in the topsoil at the end of two rotations was 106, 105 and $104 \mathrm{mg} / \mathrm{kg}$ of soil reciprocally. When growing winter wheat after sugar beet in crop rotation, it was observed an increase of mobile phosphorus in topsoil till 113, 118 and $120 \mathrm{mg} / \mathrm{kg}$ of soil.

The provision of soil with mobile potassium depends on the soil variety, the zone of humidification and the saturation of the soil-absorption complex with this element $[1,6]$.

The results of the research showed that cultivating peas for grain after spring barley in the cereal-wide raw crop rotation (share in crop rotation - 25\%), clover in cereal-grass-wide raw crop rotation (share in crop rotation - 25\%) increased the content of mobile potassium till 86 and $78 \mathrm{mg} / \mathrm{kg}$, then as for the saturation of cereal-sugar beet rotation with wide raw crops up to $50 \%$, including corn sawed with peas for silage - $25 \%$, the content of mobile potassium in the topsoil was $71 \mathrm{mg} / \mathrm{kg}$ of soil. Reducing the content of mobile potassium in the soil can be explained by the intensive it removal by crops such as buckwheat and corn for silage, as well as the transition of potassium into unchangeable-fixed state.

Significant decrease the content of mobile potassium in podsolic black soil was observed saturation of crop rotation with buckwheat. Thus, when growing buckwheat in crop rotation after spring barley, the content of mobile potassium in the topsoil was $66.5 \mathrm{mg} / \mathrm{kg}$, in the subsoil $-50 \mathrm{mg} / \mathrm{kg}$, which was determined to be smaller compared to cereal-grass-wide raw crop rotation, respectively per $15 \%$ and $20 \%$.

In the crop rotation where the buckwheat was sown after peas, the content of mobile potassium in the topsoil and subsoil layer was slightly higher, and equaled respectively 70.0 and $60.6 \mathrm{mg} / \mathrm{kg}$ of soil. 
Increasing the content of mobile potassium in the soil can be a consequence of the positive effects of biological nitrogen. The saturation of crop rotation with bean crops up to $25 \%$ increased the content of mobile potassium in soil in other crop rotations also, while the absence of legume predecessors and the saturation of crop rotation with buckwheat up to $25 \%$ and with corn sawn with peas for silage up to $25 \%$ reduced the content of mobile potassium in the soil.

\section{Conclusions}

1. The highest content of organic matter in podsolic black soil on the completion of two rotations of short-term cereal-sugar beet crop rotations with applying 7.5 tons of manure + N45P30K35 per hectare was determined by the share of wide raw crops in crop rotation - $25 \%$, perennial grasses - $25 \%$, cereals $50 \%$, and also in crop rotation: legumes - $25 \%$, cereals - $50 \%$, reciprocally $3.64 \%$ and $3.62 \%$.

2. The physical-chemical properties of podsolic black soil for increasing the percentage of wide raw crops in the crop rotation up to $50 \%$ were degraded: $\mathrm{pH}$ of salt solution - 5,7-5,6, $\mathrm{Hg}-2,2-2,5 \mathrm{mg}$ eqv./100 g, $\mathrm{S}-23.6-22.0 \mathrm{mg}$ eqv. $/ 100 \mathrm{~g}$ of soil. Reducing the share of wide raw crops up to $25 \%$ improved the physical and chemical properties of the soil.

3. Saturation of the crop rotation with wide raw crops and cereals did not affect the phosphate regime in podsolic black soil. By saturation of crop rotation with buckwheat up to $25 \%$ and corn sown with soybean for silage up to $25 \%$ it was observed a decrease of mobile potassium in the soil.

\section{Bibliography}

1. Ivanina V.V. (2016). Biolohizatsiia udobrennia kultur u sivozminakh: monohrafiia. Kyiv: TsP «Komprynt». $328 \mathrm{~s}$.

2. Minakova O.A., Gromovik A.I., Aleksandrova L.V., Tambovtseva L.V. (2010). Prognoz azotnogo i gumusnogo sostoyaniya chernozema vyshchelochennogo $v$ zernosveklovichnom sevooborote Lesostepi TsChR. Sakharnaya svekla. № 1. S. 19-20.

3. Nikul'nikov I.M. (2005). Gumusnoe sostoyanie i produktivnost' kul'tur v sevooborotakh v sistemakh zyablevoy obrabotki chernozema $\vee$ Tsentral'no-Chernozemnoy polose. Doklady Rossiyskoy akademii sel'skokhozyaystvennykh nauk. S. 1.

4. Gromovik A.l. (2016). Izmenenie soderzhaniya i sostava gumusa chernozemov Lesostepi TsChR pri raspashke. Sakharnaya svekla. № 6. S. 24-26.

5. Devyatova T.A. (2006). Izmenenie fiziko-khimicheskikh i agrokhimicheskikh svoystv chernozemov Tsentra Russkoy ravniny pri ikh sel'skokhozyaystvennom ispol'zovanii. Agrokhimiya. № 4. S. 5-8.

6. Tsvey Ya.P., Ivanina V.V., Voronyuk N.N., Dubovyy Yu.P. (2013). Ob effektivnosti elementov biologizatsii v zernosveklovichnom sevooborote. Sakharnaya svekla. № 5. S. 18-20.

7. Tsyuk A.A. (2013). Otsenka i ekologicheskaya effektivnost' sistem zemledeliya. Sakharnaya svekla. № 6. S. 25-28.

8. Kochl A. (1982). Phosphor schmeckt der Rube gut. Agrozucker. N 1. S. 313-331.

9. Brauer-Siebrecht W., Jacobs A ., Koch Henz-Josef. (2015). Stickst of fbilanz und- auswaschung in Fruchtfolgen mit Zucckerrüben und silomais. Zuckerrübe. Jg. 64. № 5. S. 22-24.

10. Schonberger H. (2015). Wie Viel Stickstoff brauchen die Zuckerrüben. Zuckerrübe. Jg. 64. № 2. S. $38-41$. 